Author(s):

Mitchell S. V. Elkind, MD ${ }^{1,2}$

\title{
Walking Is Falling
}

\section{Corresponding Author:}

Mitchell S. V. Elkind

mse13@cumc.columbia.edu

Affiliation Information for All Authors: 1. Department of Neurology, Vagelos College of Physicians and Surgeons, Columbia University, New York, NY 2. department of Epidemiology, Mailman School of Public Health, Columbia University, New York, NY

Neurology® Published Ahead of Print articles have been peer reviewed and accepted for publication. This manuscript will be published in its final form after copyediting, page composition, and review of proofs. Errors that could affect the content may be corrected during these processes. 


\section{Contributions:}

Mitchell S. V. Elkind: Drafting/revision of the manuscript for content, including medical writing for content; Major role in the acquisition of data; Study concept or design; Analysis or interpretation of data

Number of characters in title: 20

Abstract Word count: N/A

Word count of main text: 297

References: 0

Figures: 0

Tables: 0

Search Terms: [ 16 ] Clinical neurology examination, [ 51 ] Other Education, [ 90 ] Professional conduct and ethics, [ 163 ] Gait disorders/ataxia

Acknowledgements: N/A

Study Funding: The authors report no targeted funding

Disclosures: The author reports no disclosures relevant to the manuscript. 


\section{Walking Is Falling}

I think of this watching him walk today.

Now he shuffles, stoops, and slips at times.

His foot in an act of faith rises--

Barely clears my office floor,

And returns again,

Each step, a whispered prayer.

He ran a business,

Led a church,

Raced a marathon at 70,

His son proudly tells me.

I am reminded of delivering babies in med school,

How after the pain and struggle,

Gravity did the work,

The trick not pulling the baby out, but holding it back,

So the tissue wouldn't tear when the baby dropped.

Or how, at a year old, my own boys stumblewalked,

Giggling with each tumble,

Toddler knees bent, their feet and toes

A series of fat circles.

From two on we are misled.

We climb over rocks and scramble up hillsides.

Too soon we take the stairs two at a time,

And go for long walks in the woods

Branches crackling underfoot

Certain with easy hubris

That like storm-tossed trees

Our strength keeps us from toppling,

Not the ground that holds us up.

With time, each step

Is less taken than given,

Each footfall, a fall averted.

For now, that is enough,

For him, for us.

--Mitchell S. V. Elkind, MD, MS 


\title{
Neurology
}

\author{
Walking Is Falling \\ Mitchell S. V. Elkind \\ Neurology published online February 10, 2022 \\ DOI 10.1212/WNL.0000000000200167
}

This information is current as of February 10, 2022

Updated Information \& Services

Subspecialty Collections

Permissions \& Licensing

Reprints including high resolution figures, can be found at:

http://n.neurology.org/content/early/2022/02/10/WNL.0000000000200167. citation.full

This article, along with others on similar topics, appears in the following collection(s):

Clinical neurology examination

http://n.neurology.org/cgi/collection/clinical_neurology_examination

Gait disorders/ataxia

http://n.neurology.org/cgi/collection/gait_disorders_ataxia

Other Education

http://n.neurology.org/cgi/collection/other_education

Professional conduct and ethics

http://n.neurology.org/cgi/collection/professional_conduct_and_ethics

Information about reproducing this article in parts (figures,tables) or in its entirety can be found online at:

http://www.neurology.org/about/about_the_journal\#permissions

Information about ordering reprints can be found online:

http://n.neurology.org/subscribers/advertise

Neurology ${ }^{\circledR}$ is the official journal of the American Academy of Neurology. Published continuously since 1951, it is now a weekly with 48 issues per year. Copyright (C) 2022 American Academy of Neurology. All rights reserved. Print ISSN: 0028-3878. Online ISSN: 1526-632X.

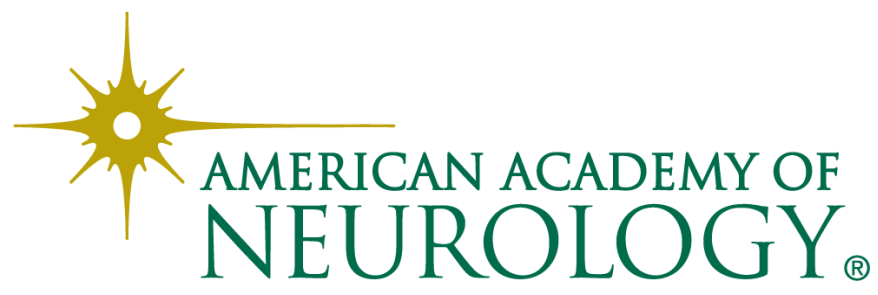

